\title{
Exploration on Constructing 3-Dimensional Teaching Model in Comprehensive English
}

\author{
Xianxian Wang \\ Department of Foreign Studies, Dezhou University, Shandong, China
}

\begin{abstract}
Due to the restrictions of traditional teaching model, serious problems emerge in Comprehensive English teaching, which hamper the practical competence of English major students. Based on the essentials of John Dewey's pragmatic ideas, this study explores and proposes the 3-dimentional teaching model in Comprehensive English and aims to promote English basic skills, innovative thinking intelligence and professional practical competence of the English major talents.
\end{abstract}

Index Terms - comprehensive English, pragmatism, 3-dimension, teaching model

\section{BACKGROUND OF THE STUDY}

Highly-qualified English major talents are in great demand in the 21st century. The Ministry of Education (2000) issued the teaching syllabus of English major which stressed the five essentials demands on the English major talents. The five demands includes: solid lingual competence, broad knowledge, professional knowledge, high capability as well as the high moral quality.

Comprehensive English is stipulated as the one of the core courses of English major curriculum of higher learning during the first two years which constitutes about 108 teaching hours each term and spanning 4 terms. It accounts for the most teaching hours in the English major course in accordance with the English major curriculum. According to the course description by the teaching syllabus of English major of Higher Learning, this course aims to cultivate students' overall English language proficiency, such as listening, speaking, reading, writing, and translating via intensive text analysis. Further, it also projects to cultivate highly qualified English talents in the long term.

Comprehensive English is one of core courses of English major, which stresses the integrated skills. It is a core course with Chinese characteristics (Li Guanyi, 1995). The development of teaching model of Comprehensive English undergoes three phases.

The first phase: 1950s-1970s

Developing from the English Intensive Reading in the 1950s under the influence of the Soviet teaching model and the Chinese traditional teaching model, the English Intensive Reading took the "reading- recitation" model with the text analysis as the key task that teachers analyzed the vocabulary, phrases and sentences word by word and intensified them through grammar, translation and writing drills. Besides, English pronunciation and intonation, English grammar and Extensive Reading were regarded as the supportive courses to English Intensive Reading. For a certain period, the "reading- recitation" model guaranteed the solid English basis for the English major. However, with the introduction of western linguistic and teaching theories and methodologies and improving of the environment of foreign language learning and this model was being questioned.

The second phase: $1980 \mathrm{~s}-1990 \mathrm{~s}$

The late 1970s saw an increasing international communication and English speaking played an ever increasingly significant role in international exchange. With the introduction of western linguistic and teaching theories and methodologies, scholars at home gained a deep insight into foreign language teaching. As far as English Intensive Reading was concerned, the teacher-centered teaching model didn't fit the cultivation on students' critical thinking competence and analytical capability, and the teaching material was out of date and lacked realistic instructions, the Intensive Reading textbooks had little connection with listening, speaking and extensive reading books. Communicative teaching theory has updated the foreign language teaching ideas at home. The English teaching syllabus for the elementary level of English major of higher learning (1989) transformed English Intensive Reading into Comprehensive English. The task of Comprehensive English stated by the syllabus was to impart the basic language knowledge to the students systematically, to train them the basic language skills- listening, speaking, reading and writing and to cultivate students' communicative competence.

Although the traditional teacher-centered teaching model has been widely adopted in Comprehensive English teaching, it turns out that the interaction between teachers and students is kind of unilateral information transmission, with memorization as the major teaching approach. Teachers play the dominant role in class who mainly impart the information while students play the subordinate role and are passively exposed to the information. The process of a unit could be generalized as" to preview the new words, analyze text structure, paraphrase language points, explain grammar and complete exercises". The monotonous process ignores cultivation of students' thinking intelligence and puts students into a passive position. Under the influence of traditional teaching concept, currently, the traditional teaching 
model are still greatly employed in Comprehensive English class, which hampers students' learning motivation, learning interest and ingenuity.

The third phase: from 2000 till today

The teaching syllabus for English major of higher learning (2000) depicts Comprehensive English as through language skills training and discourse analysis, students' lingual skills as listening, speaking, reading, writing, and translating will gradually improve and teachers instruct the students in acquiring communicative competence through various communicative activities in class. Through the new syllabus, the objective of Comprehensive English could be interpreted as first, to cultivate students' overall language skills comes as the basic objective of the course; second, to cultivate students' critical and innovative thinking competence comes as the primary objective of the course; and third, to cultivate students' all-round practical capacity comes as the ultimate objective of the course.

John Dewey (1859-1952) is a leading representative of Pragmatic education philosophy as well as a famous educator and philosopher of the $20^{\text {th }}$ century. His major masterpiece has left a profound influence to education since the $20^{\text {th }}$ century. His major masterpiece included "Democracy and education" published in 1916. His Pragmatic education ideas as well as the establishment of education philosophy as an independent subject were fully reflected in "Democracy and education". John Dewey's Pragmatic ideas in the late $19^{\text {th }}$ century transformed the traditional American education into modern. The fundamental Pragmatic idea lies is the essence of education-namely, education is life; education is growth; education is experience, which serves to be the basics for Pragmatic Thinking Intelligence ideas, curriculum theory, and active occupation theories. Besides, his major reflections on "students-centered" teaching model, "learning by doing", "reflexive thinking intelligence" and " 5 -step situational teaching" has left great instructions to modern teaching.

The study on John Dewey's education philosophy and educational ideas in China has entered a new stage since 1979. It has been noted the connection of pragmatic education philosophy with the practical life in a rational way. Shan Zhonghui (2007) states the realistic instructions of pragmatic education philosophy reveals: first, to re-think the education objective; second, to further explore the curriculum and teaching method; third, to insist on education experiment.

Realistic instructions to current English teaching reform could be learned from John Dewey's thoughts. With regard to the teaching of the core course of English major curriculum, Comprehensive English teaching, Professor Yang Limin, from Beijing University of Foreign Studies states that enhancement of students' critical thinking should be paid attention to in line with Pragmatic Thinking cultivation. Currently the student-centered teaching model exhibits the Pragmatic students-centered teaching model; Situational teaching in line with Pragmatic instructions should be employed in Comprehensive English teaching.

Concerning the restrictions of traditional teaching model applied to Comprehensive English, the problems in current English teaching and the instructions of John Dewey's pragmatic ideas, it is necessary to introduce a more effective teaching model in Comprehensive English class so as to greatly enhance students' basic English language proficiency, innovative thinking and overall language practical competence.

\section{THEORETICAL FRAMEWORK}

For John Dewey, the human experience has been transmitting and developing which is the condition of the existence of education; education is the basis of common social life due to the ongoing communication of human experiences; the link between education and social life makes education work. He holds "since growth is the characteristics of life, education is all one with growing." He also points" education is life since education lasts for the whole life. He further believes that "school is the society" and the criterion to judge the value of school education is the extent to which it creates a demand for continuous growth.

John Dewey holds that the business of the school is to create an environment in which play and work shall be integrated and conducted to facilitate the desired mental and moral growth." And four points generalize his main ideas on curriculum theories: first, the curriculum design attaches importance to the unity of students, knowledge and society; second, the curriculum pattern stresses the integration of subject curriculum and active occupation; third, teaching and curriculum are united in the curriculum implementation; fourth, both external and internal worth are valued in the curriculum judgement. He proposes the exploratory learning method which attaches importance to instructing children to explore and develop their independent thinking actively. He strongly objects to the traditional teaching which had been built solely on the textbooks. He holds that the active teaching is the only way to reform the traditional teaching.

Based on the five-step in thinking, he suggests the five-step teaching approach: first, a genuine situation which includes continuous activities the students are interested in; second, a realistic question in the very situation which functions as the stimulus to encourage thinking; third, the mastery of knowledge by which the student use to deal with the question, fourth, a series of approaches to solve the problem; fifth, an opportunity which he take to reflect, assess and test the feasibility and validity of his original ideas.

Dewey believes that all thinking has two aspects, namely, a perplexed or confused situation at the beginning and a cleared-up, unified, resolved situation at the close. It tells that to adapt oneself into the environment is an essential way to cultivate thinking intelligence of human being. 


\section{ApPlication of 3-D Teaching Model in COMPREhENSIVE English}

\section{A. Teaching Objective of the 3-Dimensional Model in Comprehensive English}

Through the new syllabus, the objective of Comprehensive English teaching is as following. First, it aims to consolidate students' English basic knowledge. Secondly, it aims to enhance students' innovative thinking intelligence critically through solving various tasks in class. Thirdly, it projects to promote students' practical competence featuring English speaking proficiency.

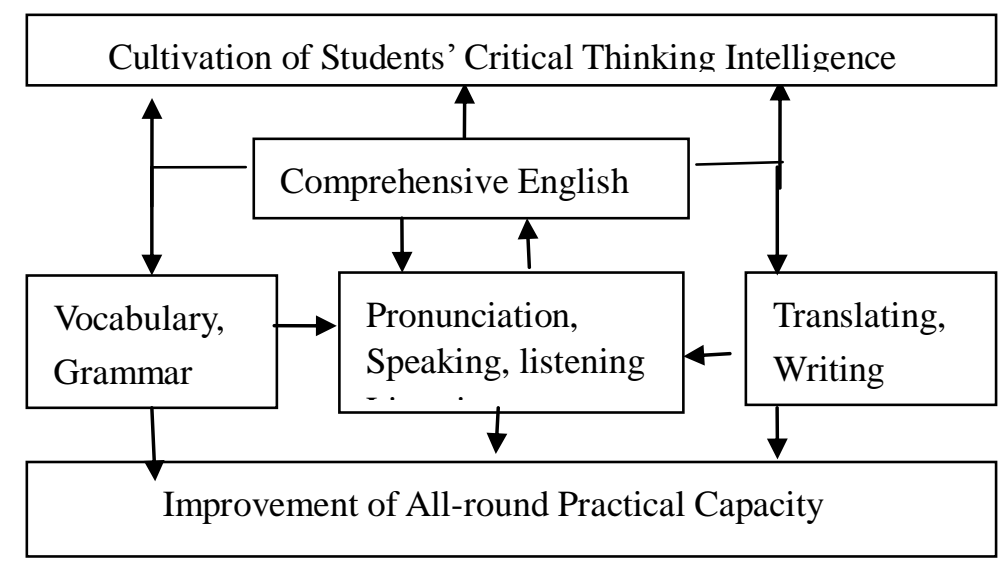

It is manifested in the graph the correlation of students' critical thinking competence, integrated language skills and overall English practical capacity. It displays that students' critical thinking cultivation lays the primary importance to advancing students' language skills systematically in that transforming, broadening, and developing students thinking intelligence activate students' motivation and interest in English learning. Through the training of integrated language skills, students' practical capacity to independently solve problems will gradually elevate.

\section{B. On the 3-Dimensional Teaching Procedures of Each Unit of Comprehensive English}

The author employs the teaching instructions to the students face to face. The 3-D teaching model is adopted in the experimental class with the Contemporary College English, textbook 3 as teaching material. The textbook may be applied to the second-year English major students for the first term. 15 units are covered in the textbook. Each section is supposed to be completed ranging 6 to 8 teaching hours.

Three-step teaching is required in Experimental class, which is pre-class preparation, in-class instruction and after-class assignment.

To prepare, students are supposed to preview the text which includes mastering the correct and standard pronunciation and intonation of new words and phrases, searching for the background information about the author and the background for creation of the text through online resources and collaborative learning. At this stage, the teacher can help the students to make the correct pronunciation of each word, or even each phoneme which students are frequently committing errors.

To search the background knowledge of the text, rich on-line resources are expected to use. Firstly, each student is expected to collect as much information independently. And then, individual student is encouraged to exchange his information with peers and the group, so broader information and ideas could be exchanged and gathered.

As for the group work, the experimental class is divided into several working groups either by design or randomly. Each group contains particular members. In the experimental class, 21 students are grouped into 5. Each group is required to make the presentation at the beginning of the comprehensive English class for one week. It clarifies that each group will make 3 presentations during classes for one week. Team members take the initiative to determine subject, content, form, the style of the performance all by themselves. They are expected to brainstorm, to collaborate and to complete the task in the simulated situations. By this way, their major knowledge and skills are intensely practiced, and their way of thinking are stimulated and their high sense of cooperation will be gradually tapped.

At the second stage of the in-class instructions, the group members are welcomed to display their presentations, and the rest of the students will make suggestions or comments on their presentation. Then, the teacher instructs in detail about intensive text analysis. During teaching, the teacher may adopt flexible method, such as debate, discussion or impromptu speech to further consolidate students' English speaking and overall English skills.

As for the after-class assignment, it is really necessary for the students to master the assignments and exercises in the final of each unit. Besides it is further a must for them to complete theme-related writing, prepared presentation and discussion to further consolidate the in-class information.

\section{Methodology}

\section{A. Purpose of the Study}


This study aims to get the first hand data with regard to Comprehensive English teaching under the 3-D teaching model and the traditional model. And it adopts experiment and interview to find out the different effectiveness between the 3-D teaching model and the traditional teaching model in Comprehensive English teaching and furthermore, aims to explore the feasibility of 3-D teaching model in Comprehensive English teaching.

\section{B. Instrument of the Study}

Tests on students' overall skills and speaking proficiency are employed in this study.

\section{Experiment}

The definition of Experimental method denotes to the "approach to educational research in which an idea or hypothesis is tested or verified by setting up situations in which the relationship between different participants or variables can be determined" (Richard, 2005, p.246)

In this experiment, two second year classes of English major are chosen as the experimental group (EG) and the control group ( $\mathrm{CG}$ )respectively. One classes of EG is taught under 3-D teaching mode in Comprehensive English class and while the other is under the traditional teaching mode in Comprehensive English class. The teachers give two classes face-to-face teaching. A teacher adopts 3-D teaching mode in Comprehensive English in the EG, emphasizing on students' speaking proficiency featured by improving students' English pronunciation and intonation, basic knowledge and innovative thinking competence with diverse teaching methods. A teacher employs traditional grammar-translation teaching model which emphasizes on students basic knowledge and skills in English learning. The two groups differ in teaching models with the identical textbooks.

1. Test on students' overall English basic knowledge and multiple-skills.

The identical teaching materials are used in two classes. The experiment lasts for two terms.

The TEM-4 test papers of 2018 and 2019 were adopted as the pretest and post-test which occurred at October, 2018 and April, 2019 respectively. The TEM-4 is the authorized, standard, systematic test which can evaluate the English major students' overall English basic knowledge and multiple-skills.

Analysis on the scores of TEM-4 of 2018 employed as the pretest

Table 4.5 shows the statistics of the scores TEM-4 of 2018 as the pretest. One non-directional test is carried out to assess the significance at the 5 percent level. Group 1 represents the EG and Group 2, CG.

\begin{tabular}{|c|c|c|c|c|c|}
\hline \multicolumn{6}{|c|}{ Group Statistics } \\
\hline & group & $\mathrm{N}$ & Mean & Std. Deviation & $\begin{array}{l}\text { Std. Error } \\
\text { Mean }\end{array}$ \\
\hline \multirow[t]{2}{*}{ pretest } & 1 & 22 & 53.0455 & 5.66087 & 1.20690 \\
\hline & 2 & 22 & 52.2727 & 7.45259 & 1.58890 \\
\hline
\end{tabular}

The above table shows that the mean score of Group 1 is 53.04 and that of the Group 2, 52.27, which is slightly lower than Group 1. And the pretest tells that both group show a relatively low score in the TEM-4 of 2018 and the students' basic knowledge and overall competence from two groups urgently needs improving. More detailed report reveals in the next table.

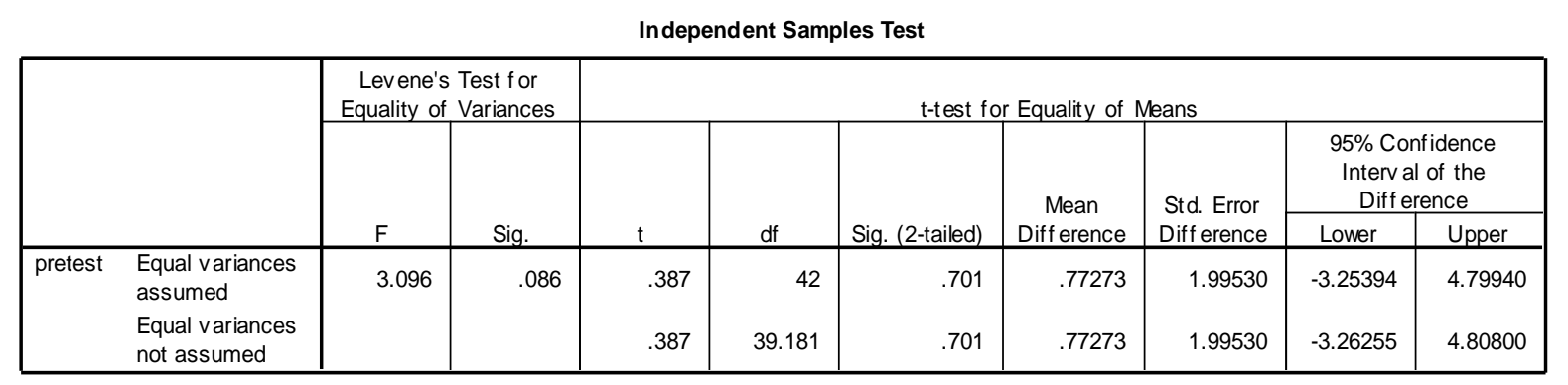

The above table reveals the statistics that are critical to evaluate the English basics of both groups. The Table 4.8 shows, the value in the column labeled Sig. is 0.086 , which is greater than 0.05 . This tells that the two groups have equal variances. In this case, the statistics in the row labeled Equal Variances Assumed is referred to.

With the critical value of the statistics $t$ for the $5 \%$ significance level, the calculated value of is 0.701 , which is less than the critical value. It indicates that the pretest scores of both groups have no significant difference. It further tells that both groups have similar English basic language foundation, which is far from satisfying and urgently need improving through further study, however, the mean score of Group 1 is slighter higher than Group 2.

Analysis on the scores of TEM-4 of 2019 employed as the post-test. 


\begin{tabular}{|c|c|c|c|c|c|}
\hline \multicolumn{6}{|c|}{ Group Statistics } \\
\hline & group & $\mathrm{N}$ & Mean & Std. Deviation & $\begin{array}{l}\text { Std. Error } \\
\text { Mean }\end{array}$ \\
\hline \multirow[t]{2}{*}{ posttest } & 1 & 22 & 61.2727 & 7.06556 & 1.50638 \\
\hline & 2 & 22 & 56.7273 & 7.22550 & 1.54048 \\
\hline
\end{tabular}

The table above shows that the mean score of Group 1 is 61.27 and that of the Group 2, 56.73, which is about 4.15 points lower than Group 1. And statistics tells that both groups under the two different teaching models have enjoyed a progress through two terms learning compared with the pretest and the improvement of the scores of Group 1 under the 3-D teaching model is greater than Group 2 under the traditional teaching model. And further details reveals in the following table.

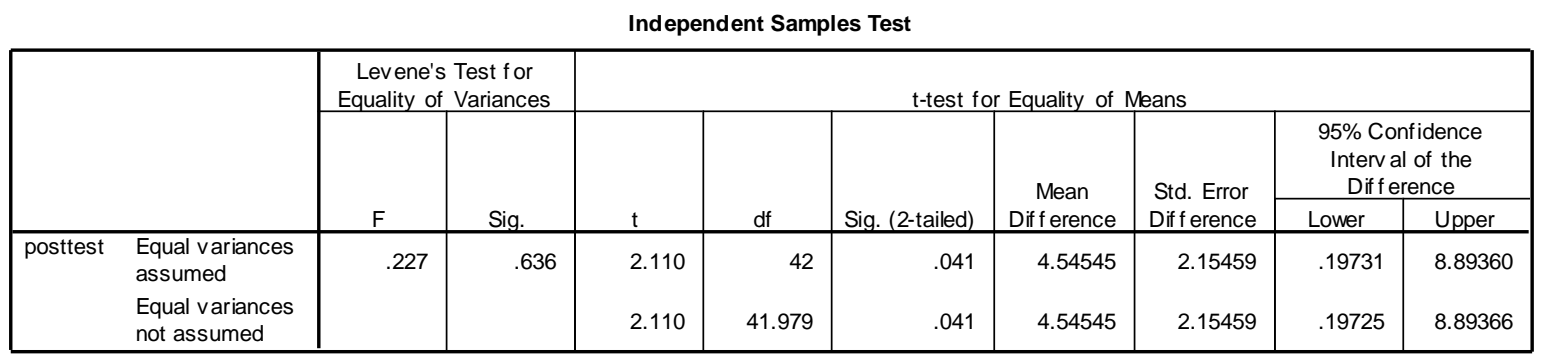

The table above reveals the statistics that are critical to evaluate the English basics of both groups. The second table shows, the value in the column labeled Sig. is 0.636 , which is greater than 0.05 . This tells that the two groups have equal variances. Thus, the statistics in the row labeled Equal Variances Assumed is used.

With the critical value of the statistics $t$ for the $5 \%$ significance level, the calculated value of is 0.041 which is less than the critical value. It reveals that the post-test scores of both groups have significant difference.

The following statistics further imply that the 3-D teaching model has more positive and greater effect on the enhancement of scores than the traditional model. During two terms of learning, both groups have seen a progress in their scores, which means that the students' English basic knowledge and multiple-skills have developed. However, on the whole, the overall improvement of Group 1 is more considerable than Group 2 and the mean score of Group 1 is about 4.5 point higher than Group 2 .

\begin{tabular}{|c|c|c|c|c|c|}
\hline \multicolumn{6}{|c|}{ Descriptive Statistics } \\
\hline & $\mathrm{N}$ & Minimum & Maximum & Mean & Std. Dev iation \\
\hline posttest & 22 & 44.00 & 73.00 & 61.2727 & 7.06556 \\
\hline Valid N (listwise) & 22 & & & & \\
\hline
\end{tabular}

\begin{tabular}{|l|r|r|r|r|r|}
\hline & Descriptive Statistics \\
\hline posttest & N & Minimum & Maximum & Mean & Std. Dev iation \\
Valid N (listwise) & 22 & 40.00 & 70.00 & 56.7273 & 7.22550 \\
\hline
\end{tabular}

Through the statistics of the two tables above, it could see that students in the experimental class are more adapted to the 3-D teaching model and are more active in the Comprehensive English class compared with the traditional teaching model and therefore, they have made much greater progress through two terms of endeavors. The significant difference of the post-test scores indicates that students' overall language competence of experimental class is more solid than the controlled class despite the poor language basics of both groups at the very beginning of the experiment. The passing score is 60 point. And the mean score of Group 2, 56.72, which is much lower than 60 point, implies that the overall English studying condition of the class is far from satisfying that about $50 \%$ of the students fail the exam and lack proper competence in English learning.

Tests on English speaking proficiency

Analysis on the scores of the students' English pronunciation and intonation of the experimental class

In order to test the improvement of students speaking proficiency, two tests on English speaking were given to the students from the experimental class which were conducted in early September, 2018 and early January, 2019. Both test 
papers of identical level cover: first, the distinction of English sounds, second, reading aloud the English phrases, third, intonation of English sentences, fourth, reading aloud English passages and English speech, which aim to check students English pronunciation, intonation and English speaking fluency as well. Through one term of learning, the analysis of the pretest and post-test of the experimental class is listed as following:

4.3.2 Analysis on the scores of the pretest and the post-test on students' speaking proficiency.

Paired Samples Statistics

\begin{tabular}{|c|c|c|c|c|c|}
\hline & & Mean & $\mathrm{N}$ & Std. Dev iation & $\begin{array}{c}\text { Std. Error } \\
\text { Mean }\end{array}$ \\
\hline \multirow{2}{*}{$\begin{array}{l}\text { Pair } \\
1\end{array}$} & pretest & 72.1818 & 22 & 6.29161 & 1.34138 \\
\hline & posttest & 78.2273 & 22 & 7.61535 & 1.62360 \\
\hline
\end{tabular}

Paired Samples Test

\begin{tabular}{|c|c|c|c|c|c|c|c|c|}
\hline & \multicolumn{5}{|c|}{ Paired Diff erences } & \multirow[b]{3}{*}{$\mathrm{t}$} & \multirow[b]{3}{*}{ df } & \multirow[b]{3}{*}{ Sig. (2-tailed) } \\
\hline & \multirow[b]{2}{*}{ Mean } & \multirow[b]{2}{*}{ Std. Dev iation } & \multirow{2}{*}{$\begin{array}{c}\text { Std. Error } \\
\text { Mean }\end{array}$} & \multicolumn{2}{|c|}{$\begin{array}{l}95 \% \text { Confidence } \\
\text { Interv al of the } \\
\text { Dif f erence }\end{array}$} & & & \\
\hline & & & & Lower & Upper & & & \\
\hline Pair 1 pretest - posttest & -6.04545 & 3.76041 & .80172 & -7.71273 & -4.37818 & -7.541 & 21 & .000 \\
\hline
\end{tabular}

The two tables above display the pretest mean score of the experimental class is 72.18 and that of the post-test is 78.22, which shows a considerable increase than the pretest. The next statistics from the table reveals that there is a considerable difference between the scores and the 3-D teaching model has a significant effect on the enhancement of students' speaking proficiency.

\section{A Record of Student' Practical Activities}

Class presentation is instrumental to promoting students' innovative thinking and professional capacity. The diversified class presentation involves each student in the experimental class. They have demonstrated different forms and further developed their overall skills. The first round of class presentations by five groups of experimental class from October and November, 2019 is listed in the following table.

\begin{tabular}{|c|c|c|}
\hline Group & Time & Form \\
\hline 1 & 12th, 10-16th, 10 & $\begin{array}{l}\text { 1. Interview: University education } \\
\text { 2. Debate: To live to learn? To learn to live? } \\
\text { 3. Speech: The meaning of live }\end{array}$ \\
\hline 2 & 19th, 10-23th,10 & $\begin{array}{l}\text { 1. Solo singing: Eyes on me } \\
\text { 2. Drama show on Chinese classic play: Mulan's Story } \\
\text { 3. DIY fashion design performance }\end{array}$ \\
\hline 3 & 26th, 10-30th,10 & $\begin{array}{l}\text { 1. Speech : Business Ethic and Low carbon life } \\
\text { 2. Drama show: The little red hat } \\
\text { 3. Cross-talk show in English }\end{array}$ \\
\hline 4 & 10th,11-14th, 11 & $\begin{array}{l}\text { 1. Impromptu speech: Garbage Classification } \\
\text { 2.Impromptu Rap show } \\
\text { 3.Musical instrument play: Guitar playing }\end{array}$ \\
\hline 5 & 15th, 11-19th, 11 & $\begin{array}{l}\text { 1.Speech: Steve Jobs' story } \\
\text { 2.Interview performance: Hunting for Jobs and Interview } \\
\text { 3. Impromptu solo singing }\end{array}$ \\
\hline
\end{tabular}

The above table shows that each group has revealed diverse forms of class presentations. During the preparation, they are interested and active in thinking and designing the forms and style of their performance. The members in group one are relatively shy and the forms of presentation seem a bit conservative and in the following weeks, more students grow to realize the significance and effect of the teamwork, they turn to more attentive to brainstorming and exploring more creative forms.

\section{MAJOR FINDINGS AND LIMITATIONS}

It has apparently improved the correctness of students' English pronunciation and intonation as well as the fluency of English speaking. Students' awareness of grasping standard English pronunciation and intonation and the fluent oral English has been strengthened. The situational tasks develop students' overall English language ability step by step. Through the entire model of full training process, students are able to communicate in the interactive activities. It stimulates students' critical thinking capacity and practical capacity. In the simulated situations in class, students are encouraged by the teacher to think independently and solve the problem though either individual work or teamwork and students expected and welcome to regard the tasks from different perspectives and speak out their ideas, exchange the 
ideas, discuss or debate with each other.

In spite of the findings of the tentative study, certain limitations still exist and remain for further discussion. The limitations of the present research along with the corresponding suggestions for further research are listed. First, the number of the subjects involved is just limited, which may possibly affect the validity and reliability of the experiment. It would be more reliable if it could apply to more classes or in different universities. Second, the diverse class demonstrations are just part of the reflection of the enhancement of students' critical thinking competence, whereas, not a complete reflection. Students' professional capacity shall be enhanced through various ways. Moreover, the speaking proficiency test only applies to the experimental class. It would be more objective if it could extend to both the experimental and the controlled class.

To conclude, the 3-D teaching model in Comprehensive English class is not just a passing experience; it will be necessary to explore the reform in English teaching to further enhance the overall quality of students in the newly-established colleges.

\section{REFERENCES}

[1] Breen, M. and Candlin, C. N. (1980). The Essentials of Communicative Curriculum in Language Teaching. Applied Linguistics, (1) $40-43$

[2] D.Tanner. Curriculum Development, Theory into Practice. New York: Macmillan.

[3] Dongchun Chen. (2007). Improvement of English Major Competence in $21^{\text {st }}$ Century [J]. Foreign Language Teaching and Studying 1, 53-56

[4] Ellis R. (1999). The Study of Second Language Acquisition .Shanghai: Shanghai Foreign Study Publisher.

[5] Jack,C.\& Richard, S. (2005). Longman Dictionary of Language Teaching and Applied Linguistics. Beijing: Foreign Language Teaching and Research Press.

[6] Jim Scrivener. (2002). Learning Teaching: a Guidebook for English Language Teaching. Shanghai: Shanghai Foreign Language Study Press.

[7] John Dewey. Translator: Xucheng Wang. (2001). Democracy and Education. Beijing: People's Education Press.

[8] John Dewey. (1916). Democracy and Education .New York; Macmillan.

[9] John Dewey. (1963). Experience and Education. New York: Collier Books.

[10] Ruiqing Du. (1992). Cultivation of All-round English Talents and Practice. Foreign Language Teaching 2, 78-84

[11] Stern H H. (1999). Issue and opinions in Language Teaching. Shanghai: Shanghai Foreign Study Publisher.

[12] Zhang Chuting. (2003). Curriculum and Teaching Philosophy. Beijing: People's Education Publisher.

[13] Zhonghui Shan. (2002). John Dewey and Pragmatism. Beijing: People's Education Press.

Xianxian Wang was born in Dezhou, China in 1980. She studied at the School of Foreign Studies in Shandong University of Finance and Economy from 1999-2003, English major. She received her M.A in Shandong Normal University from 2009-2012.

Since 2003, she has worked in the foreign language department in Dezhou University. Her professional title is lecturer. Her research interest includes: English curriculum and teaching, English phonetics. She won the title of the "most promising young teachers in Dezhou University" in 2012. And she was the second prize winner for the "excellent research paper" in the Shandong Provincial teaching forum host by Shandong Provincial Department of Education. 